\title{
Rational acyclovir therapy in herpetic eye disease
}

\author{
M G FALCON \\ From the Department of Ophthalmology, St Thomas's Hospital, London SE1 7EH
}

SUMMARY Acyclovir has been widely used against the various manifestations of eye disease due to herpes simplex since it first became generally available in the UK nearly five years ago. This paper discusses the rational indications for its use, through considerations of its pharmacology and pharmacokinetics, and through results of the many clinical trials that have been carried out to investigate its effects since its clinical efficacy was first demonstrated in 1979.

\section{Pharmacology and pharmacokenitics of acyclovir}

The antiviral effect of acyclovir (ACV) was first described by Elion et al. in $1977^{1}$ and subsequently by Schaeffer $e t$ al. ${ }^{2}$ and Bauer $e t$ al. ${ }^{3}$ It was the result of a systematic search for a specific "antiherpes antiviral that exploits the fact that cells replicating these viruses, and particularly herpes simplex virus (HSV), are induced by the virus to produce thymidine kinase (TK). This enzyme activates ACV to the monophosphate-the first stage in the antiviral action of the drug that gives it an overall $\mathbf{3 0 0 0}$ fold greater effect against HSV replication than against host cell synthesis. ACV itself is inactive, and its lack of toxicity not only allows prolonged topical therapy if necessary, but also systemic therapy-a fact that has made dramatic improvements in the management of herpes simplex virus infections in immunocompromised patients ${ }^{4}$ and in those with herpes simplex encephalitis. ${ }^{5}$ Toxicity from topical ocular therapy with idoxuridine, trifluorothymidine, and adenine arabinoside has become widely recognised. ${ }^{6}$

Topical application of ACV to the eye leads to therapeutic levels in the aqueous, even when the epithelium is intact, ' though there have been suggestions that the stromal levels from $3 \%$ ointment may be suboptimal. ${ }^{8}$ Oral therapy also leads to adequate levels of $A C V$ in tears and aqueous, ${ }^{9}$ for $A C V$ crosses the blood-aqueous barrier.

It is not difficult to isolate strains of HSV that are ACV resistant: they are relatively or completely independent of TK. ${ }^{10}$ These strains are, however, of low virulence, and clinical problems with ACV resistance have been minor; but they could increase with increasing use of the drug.

Correspondence to MG Falcon, FRCS.

\section{Rational use of acyclovir}

PRIMARY HERPES SIMPLEX

Recent figures for the serological evidence of past (primary) herpetic infection vary between approximately $30 \%{ }^{11}$ and $80 \%,{ }^{12}$ but overt primary herpes occurs in only a small proportion of these individuals. By implication the condition is often very minor and self limiting, though ocular involvement may ensue, ${ }^{13}$ and a severe disease can occur in immunocompromised $^{14}$ or atopic persons. ${ }^{15}$ Neonates can suffer a severe ocular disease from HSV types 1 or 2 , with conjunctivitis, keratitis, choroidoretinitis, optic neuropathy, and cataract. ${ }^{16}$ Herpes encephalitis and a variety of other effects on the CNS can follow primary herpes. ${ }^{17}$ Transneuronal spread can occur, so that the eye can be the site of recurrence from primary herpes elsewhere. ${ }^{18} 19$ This may also be one explanation for bilateral herpetic keratitis.

It is obviously essential to treat patients who have a serious form of primary herpes simplex. ACV is the drug of choice, since the systemic route will often be required. Topical treatment to skin lesions with IDU and even with ACV has little proved benefit, though topical treatment might be of benefit in preventing canalicular involvement, which has been shown to be a potent cause of canalicular obstruction in young people ${ }^{20}$; and topical treatment is clearly indicated if involvement of the globe follows the primary disease.

PREVENTION OF LATENCY AND RECURRENCE There is no clinical evidence that treatment of primary herpes can reduce the likelihood of latency, or recurrence, although there is experimental evidence that the early administration of ACV following HSV inoculation in the eye can reduce the 
evidence of latency. ${ }^{21}$ It is certainly the case that no means are yet available to eradicate latency once it has occurred. The presence of latent virus (of a particular strain) in the ganglion seems both to determine the clinical characteristics of the disease (in the eye $)^{2223}$ and to inhibit the entry of virus of a different strain, although this latter effect is incomplete ${ }^{24}$ Evidence is also accumulating that the cornea (and perhaps other peripheral sites) may be the site of a 'latent' viral phase from which virus can be cultured ${ }^{25}$ and seen to undergo replication in keratocytes. ${ }^{26}$ None of these new data on latency offer any further direct hope of controlling it pharmacologically (if this is, indeed, desirable). In the meantime there is the possibility of long term prophylaxis with antiviral therapy. Obvious risks are the development of toxicity, and the development of resistant strains of HSV. No firm clinical data are available (apart from the special case where steroids provide the risk factor-considered elsewhere), but it is probably best to avoid long term prophylaxis, and to reserve short term prophylaxis for those individuals who can recognise trigger factors, using prophylaxis at these appropriate times. Experimentally, local or systemic ACV will prevent recurrences if it is given before the trigger factor appears. ${ }^{27}$

\section{HERPETIC CONJUNCTIVITIS}

HSV is a common cause of conjunctivitis. ${ }^{13}$ It is often self limiting, though it can sometimes lead on to a keratitis resembling that due to adenovirus types 8 or 19 , and it represents one part of the spectrum, ranging from an absence of symptoms or signs, to frank herpetic keratitis, that can result from repeated virus shredding. Since the outcome is uncertain when these patients are first seen, and since laboratory diagnosis is often not proved, it could be reasonably argued that antiviral therapy is appropriate, but there are no grounds for favouring any particular drug.

\section{ULCERATIVE HERPETIC KERATITIS}

The clinical trial that first showed that topical ACV was effective against dendritic ulcers was constructed in such a way that a minimum quantity of the drug was used. ${ }^{28} \mathrm{~A}$ large number of trials have since been carried out comparing ACV with IDU, Ara-A and $F_{3} T$ in patients with dendritic ulcers-using this very convenient microsystem to provide precise information on healing rates, healing percentages, toxicity, subsequent deep disease, and other complications. It may seem somewhat surprising that there has not been complete agreement in the results, though comparisons across different clinical trials are notoriously insecure. The trials of Coster et al $^{29}$ and Collum et al. ${ }^{30}$ are noteworthy in this regard: the first found no difference between ACV and IDU, whereas the second found ACV to be superior. The most cautious conclusion overall is perhaps that for patients with dendritic ulcers, which represent a simple task for the antiviral agent, no antiviral has been repeatedly demonstrated to be superior to any other. It could be argued that IDU should be used initially because it is effective and inexpensive and AVC should be reserved for possible future events such as disciform keratitis, where its particular advantages will be realised, or for circumstances where oral therapy is preferably to local, ${ }^{31} \mathrm{ACV}$ being effective by either route. ${ }^{9}$ As already indicated, the primary use of ACV would be likely to select for ACV resistant strains of HSV, although these have not been a problem in clinical practice, perhaps because these strains are of low virulence.

Amoeboid ulcers present a more challenging problem for an antiviral than do dendritics, and their prognosis is worse in every way. ${ }^{32}$ Clinical trials demonstrated a superiority of $\mathrm{F}_{3} \mathrm{~T}$ over Ara-A, ${ }^{33}$ but $A C V$ and Ara-A were recently shown to have equivalent effects. ${ }^{34}$ Probably an important issue is the entry of the antiviral into the stroma, which will occur with $F_{3} T$ when the epithelium is breached and with ACV even when it is intact, since there may be replicating stromal virus in these patients. Either drug is thus preferable to IDU or Ara-A. However, $\mathrm{F}_{3} \mathrm{~T}$ is not readily available in the $\mathrm{UK}$, whereas it is marketed in the USA, but ACV is not.

Indolent ('metaherpetic') ulcers are perpetuated by such factors as antiviral toxicity, loss of corneal sensation, damage to basement membrane, stromal disease, and tear film inadequacy; and, by definition, viral replication is not occurring in the epithelium. This is not always the case in the stroma, ${ }^{35}$ but even if the stromal disease is not being caused by viral replication, there may be a need for antiviral therapy to 'cover' steroid therapy. It seems reasonable to suggest that ACV should be the antiviral of choice in these patients: firstly, because it is the least toxic antiviral, and secondly because it has good ocular penetration.

\section{KERATOUVEITIS}

Numerous experimental and clinical studies have shown that deep keratitis and/or uveitis can be caused by viral replication or various immune mechanisms, and it is probably safest for the clinician to consider that both mechanisms are usually occurring, though to differing degrees in different patients, with the various forms of herpetic keratouveitis. $\mathrm{Oh}^{36}$ has produced evidence that viral replication may occur in primary HSV uveitis but not recurrent disease (the latter being commoner clinically). But viral replication may undoubtedly be triggered off by steroid therapy ${ }^{37}$ both in the epithelium and in the stroma, 
and the use of a penetrating antiviral during steroid therapy for stromal disease appears logical.

Both steroids and ACV have been useful investigative tools in HSV keratouveitis. Collum and colleagues' demonstration ${ }^{38}$ of the benefit from ACV and betamethasone compared with ACV alone in patients with disciform keratitis was the first trial to prove the short term value of steroids in this disease - a benefit nevertheless little doubted-and Colin et al. ${ }^{39}$ found that ACV was superior to $\mathrm{F}_{3} \mathrm{~T}$ or Ara-A when used in combinaton with steroids for patients with deep disease. Sundmacher ${ }^{40}$ has conversely shown a benefit from oral ACV in patients with virologically proved intraocular HSV disease, and Wilhelmus et al. ${ }^{41}$ obtained a probable benefit from topical ACV compared with IDU in patients with herpetic uveitis. van Ganswijk et al..$^{42}$ found resolution of stromal keratitis within four weeks of starting ACV therapy in 35 patients with refractory deep disease, but Sanitato et al..$^{43}$ found no benefit from $A C V$ in the management of 17 patients with herpetic stromal disease. Maudgal et al. ${ }^{44}$ obtained good effects from a water soluble derivative of ACV (applied as drops) in the treatment of experimental keratitis produced by intrastromal injection of live virus. Maudgal's group found $\mathrm{F}_{3} \mathrm{~T}$ to be superior to $3 \% \mathrm{ACV}$ ointment in this model, and suggested that a higher dosage of ACV than 3\% ointment five times a day might be required for optimal stromal levels.

From these considerations it would appear logical to treat patients with HSV keratouveitis firstly with a penetrating antiviral alone, or even to use oral therapy for HSV uveitis, and to add as little steroid as possible if there is an inadequate response to the former. In the UK ACV is the drug of choice, and its lack of toxicity makes it particularly suitable for the long term therapy that is needed to accompany long term steroid therapy.

\section{POSTERIOR SEGMENT DISEASE}

Evidence is accumulating, particularly from vitreous specimens and retinal biopsy, that acute retinal necrosis and choroidoretinitis can sometimes be caused by HSV. ${ }^{45}$ Grutzmacher $e t$ al. treated one such patient (virologically proved) with ACV successfully. ${ }^{46}$

The safety of ACV for intravitreal as well as oral use is particularly attractive. It may have a role in cytomegaloviris retinitis, though the in-vitro efficacy against CMV is not as strong as against HSV. Hydroxy ACV may prove to be superior. ${ }^{47}$

\section{KERATOPLASTY}

There has for some years been considerable discussion about the value (or otherwise) of using long term prophylactic antiviral therapy following grafting for herpes. Much of the earlier work inevitably referred only to IDU, and it was demonstrated that the risk of toxicity from this drug on the epithelium of the graft was unacceptably high. ${ }^{48}$ However, Cobo et $a l .{ }^{49}$ showed that recurrence of herpetic epithelial disease was particularly likely in patients who developed a recurrence of inflammatory disease (whether due to rejection or herpes) following keroplasty, and this emphasised the need to cover the appropriately intensive steroid therapy that was given at this time. ACV (or perhaps $F_{3} T$, if available, and if not used for too long) would be the drug of choice for reasons already mentioned.

But what of long term ACV prophylaxis following grafting? It is certainly safe, but it may be undesirable to give ACV for many months (the incidence of recurrence remaining high for over a year postoperatively). It was shown by Kok van Alphen and Volker-Dieben ${ }^{50}$ in a relatively small study that prophylaxis with ACV during the first months after operation did not appear to reduce the risk of recurrence. Probably the wisest action to take in the light of present knowledge is to give ACV prophylaxis to those patients deemed to be at a particularly high risk of recurrence, such as those requiring a high level of steroid, or those receiving a graft for therapeutic reasons (in an inflamed eye); and to give $A C V$ prophylaxis as appropriate for later episodes of inflammatory disease; but to avoid long term ACV prophylaxis for patients in relatively low risk circumstances.

\section{Conclusion}

An attempt has been made in this article, by drawing on the appropriate data from the numerous workers, both clinical and non-clinical, involved in herpetic keratitis to guide the clinician in the rational use of acyclovir. It is no accident that so much of the data originated either from Barrie Jones's department or from those whose interest in herpetic eye disease was inspired by him. Acyclovir has already made a major contribution to patients suffering from this complex disease. Future developments are likely to include combination therapy-either with interferon, which has been shown to be more effective than ACV alone ${ }^{5152}$ or a combination with antiviral drugs such as Ara-A that work at other sites, or ACV analogues that may offer advantages over the parent compound.

I am indebted to Mrs Julie Lawrence, who typed the manuscript.

\section{References}

1 Elion G, Furman PA, Fyfe JA, De Miranda P, Beauchamp L, Schaeffer HJ. Selectivity of action of an antiherpetic agent, 9-(2-hydroxyethoxymethyl)-guanine. Proc Nat Acad Sci USA 1977; 74: 5716-20. 
2 Schaeffer HJ, Beauchamp L, De Miranda P, Elion GB, Bauer DJ, Collins P. 9-(2-hydroxyethoxymethyl)-guanine. Activity against the viruses of the herpes group. Nature 1978; 272: 583.

3 Bauer DJ, Collins P, Tucker WE Jr, Macklin AW. Treatment of experimental herpes simplex keratitis with acycloguanosine. $\mathrm{Br} J$ Ophthalmol 1979; 63: 429-35.

4 Mitchell CD, Bean B, Gentry SR, Groth KE, Boen JR, Balfour $\mathrm{HH}$. Acyclovir therapy for mucocutaneous herpes simplex infections in immunocompromised patients. Lancet 1981; ii: 1389-92.

5 Sköldenberg B, Alestig K, Burman L, et al. Randomised multicentre study in consecutive Swedish patients: acyclovir versus vidarabine in herpes simplex encephalitis. Lancet 1984: 707-711.

6 Falcon MG, Jones BR, Williams HP, Coster DJ (1981). Adverse reactions in the eye from topical therapy with idoxuridine, adenine arabinoside and trifluorothymidine. In: Sundmacher R, ed. Herpetische Augenerkrankungen. Munich: Bergmanns 1981: 263-6.

7 Poirier H, Kingham JD, De Miranda P, Annel N. Intraocular antiviral penetration. Arch Ophthalmol 1982; 100: 1964-7.

8 Maudgal PC, Virjghem JC, Molemanes M, Missotten L. Effect of topical acyclovir therapy on experimental herpes simplex keratouveitis. Arch Ophthalmol 1985; 103: 1389-92.

9 Hung SO, Patterson A, Rees PJ, Pharmocokinetics of oral acyclovir (Zovirax) in the eye. BrJ Ophthalmol 1984; 68: 192-5.

10 Gordon YJ, Armstrong JA, Brown SI, Becker Y. The role of herpes virus type $I$ thymidine kinase in experimental ocular infections. Am J Ophthalmol 1983; 95: 175-81.

11 Editorial: Herpes simplex-changing patterns. Lancet 1981; ii: 1025-6.

12 Sarkies N, Gregor Z, Forsey T, Darougar S. Antibodies to herpes simplex virus type $I$ in intraocular fluids of patients with acute retinal necrosis. BrJ Ophthalmol 1986; 70: 81-4.

13 Darougar S, Wishart MS, Viswalingam ND. Epidemiological and clinical features of primary herpes simplex virus infection. $\mathrm{Br}$ J Ophthalmol 1985; 69: 2-6.

14 Easty DL. Virus disease of the eye. London: Lloyd-Luke, 1985: 167-71.

15 Easty DL. Virus diseases of the eye. London: Lloyd-Luke, 1985: 156-60.

16 Nahmias AJ, Vinistine AM, Caldwell DI, Wilson LA. Eye infections with herpes in simplex viruses in neonates. Surv Ophthalmol 1976; 21: 100-5.

17 Longson M. Herpes encephalitis. In Heath RB, ed. Virus diseases. London: Pitman, 1979.

18 Howell BJ, Narang HK, Codd AA. Herpes simplex virus, uveitis and optic neuropathy. Trans Ophthalmol Soc UK 1979; 99: 111-6.

19 Tullo AB, Easty DL, Hill DJ, Blythe WA. Ocular herpes simplex and the establishment of latent infection. Trans Ophthalmol Soc UK 1982; 102: 15-8.

20 Coster DJ, Welham RA. Herpetic canalicular obstruction. Br J Ophthalmol 1979; 63: 259-62.

21 Field HJ, Bell S, Elion GB, Nash AA, Wildy P. Effect of acycloguanosine treatment of acute and latent herpes simplex infections in mice. Antimicrob Agents Chemother 1979; 15: 544-61.

22 Kaufman HE. Antimetabolite drug therapy in herpes simplex. Ophthalmology (Rochester) 1980; 87: 135.

23 Kaufman HE, Varnell ED, Centifanto YM, Kissling GE. Effect of herpes simplex virus genome on the response of infection to corticosteroids. Am J Ophthalmol 1985; 100: 114-8.

24 Gordon YJ, Araullo-Cruz T. Herpes virus inoculation of cornea. Am J Ophthalmol 1984; 97: 482-7.

25 Shimeld C, Tullo AB, Easty DL, Thomsitt J. Isolation of herpes simplex virus from the cornea in chronic stromal keratitis. Br J Ophthalmol 1982; 66: 643-7.

26 Cook SD, Aitken DA, Lee WR, Brown SM. Herpes simplex virus in the cornea: an ultrastructural study on viral reactivation. Trans Ophthalmol Soc UK in press.
27 Blyth WA, Harbour DA, Hill TJ. Effect of acyclovir on recurrence of herpes of simplex skin lesions in mice. J Gen Virol 1980 B; 48: 417-9.

28 Jones BR, Coster DJ, Fison PN, Thompson GM, Cobo LM, Falcon MG. Efficacy of acycloguanosine (Wellcome 248U) against herpes simplex corneal ulcers. Lancet 1979; i: 243-4.

29 Coster DJ, Wilhelmus KR, Michaud R, Jones BR. Comparison of acyclovir and idoxuridine as treatment for ulcerative herpetic keratitis. BrJ Ophthalmol 1980; 64: 763-5.

30 Collum LMT, Benedict-Smith A, Hillary IB. Acyclovir in dendritic corneal ulceration. In: Trevor-Roper P, ed. The cornea and health and disease. London: RSM/Academic Press, 1980.

31 Collum LMT, Akhtar J, McGettrick. Oral acyclovir in herpetic keratitis. Trans Ophthalmol Soc UK 1985; 104: 629-32.

32 Williams HP, Falcon MG, Jones BR. Corticosteroids in the management of herpetic eye disease. Trans Ophthalmol Soc UK 1977; 97: 341-4.

33 Coster DJ, Jones BR, McGill JI. The treatment of amoeboid herpetic ulcers with adenine arabinoside or trifluorothymidine. Br J Ophthalmol 1979; 63: 418-21.

34 Collum LMT, Logan P, McAuliffe-Curtin D, Hung SO, Patterson A, Rees PJ. Randomised double blind trial of acyclovir (Zovirax) and adenine arabinoside in herpes simplex amoeboid corneal ulceration. Br J Ophthalmol 1985; 69: 847-50.

35 Jones BR, Falcon MG, Williams HP, Coster DJ. Objectives in therapy of herpetic eye disease. Trans Ophthalmol Soc UK 1977; 97: 305-13.

$36 \mathrm{Oh}$ JO. Primary and secondary herpes simplex uveitis in rabbits. Surv Ophthalmol 1976; 21: 178-84.

37 Patterson A, Jones BR. The management of ocular herpes. Trans Ophthalmol Soc UK 1967; 87: 59.

38 Collum LMT, Logan P, Ravenscroft T, Acyclovir (Zovirax) in herpetic disciform keratitis. $\mathrm{Br} J$ Ophthalmol 1983; 67: 115-8.

39 Colin J. Mazet D, Chastel C. Treatment of herpetic keratouveitis: comparative action of $\mathrm{AraA}, \mathrm{F}_{3} \mathrm{~T}$ and $\mathrm{ACV}$ in combination with corticoids. In: Maudgal PC, Mossotten L, eds. Herpetic eye disease. Dordrecht, Boston, Lancaster: Junk, 1985 227-32.

40 Sundmacher $\mathrm{R}$. Oral ACV therapy for virologically proven intraocular herpes simplex virus disease. Klin Monatsbl Augenheilkd 1983; 183: 246.

41 Wilhelmus K. Falcon MG, Jones BR. Herpetic iridocyclitis. Int Ophthalmol 1981; 4: 143-50.

42 Ganswijk R, Oosterhuis JA, Versteeg J. Acyclovir treatment in stromal herpetic keratitis. In: Maudgal PC, Missotten L, eds. Herpetic eye disease Dordrecht, Boston, Lancaster: Junk, 1985.

43 Sanitato JJ, Asbell PA, Varnell ED, Kissling GE, Kaufman HE. Acyclovir in the treatment of herpetic stromal disease. $\mathrm{Br} \mathrm{J}$ Ophthalmol 1984; 98: 537-47.

44 Maudgal PC, De Clercq, Descamps J, Missotten L. Topical treatment of experimental herpes simplex keratouveitis with 2-O-glycylacyclovir; a water-soluble ester of acyclovir. Arch Ophthalmol 1984; 102: 140-2.

45 Culbertson WW, Clarkson JG, Bloomencrantz M, Lewis ML. Acute retinal necrosis. Am J Ophthalmol 1983; 196: 683-5.

46 Grutzmacher RD, Henderson D, McDonald PJ, Coster DJ. Herpes simplex chorio-retinitis in a healthy adult. $\mathrm{Am} \mathrm{J}$ Ophthalmol 1983; 96: 788-96.

47 Pulido J, Peyman GA, Lesart, Vernot J. Intravitreal toxicity of hydroxy ACV (BW-B759U): a new antiviral agent. Arch Ophthamol 1985; 103: 840-1.

48 Rice NSC, Jones BR. Problems of corneal grafting in herpetic keratitis. In: CIBA foundation symposium on corneal graft failure. Amsterdam: Associated Scientific Publication, 1973; 15: 221-39.

49 Cobo LM, Coster DJ, Rice NSC, Jones BR. Prognosis and management of corneal transplantation for herpetic keratitis. Arch Ophthalmol 1980; 98: 1755-9. 
51 De Koning EWJ, Van Bijsterfeld P, Cantell K. Combination therapy for dendritic keratitis with acyclovir and alphainterferon. Arch Ophthalmol 1983; 101: 1866-8.

52 Colin J, Chastel C, Rinald G, Cantell K. Combination therapy for dendritic keratitis with human leucocyte interferon and acyclovir. Br J Ophthalmol 1983; 95: 346-8.
50 Kok van Alphen CC, Volker-Dieben JM. Prevention and treatment of herpes recurrence in the corneal graft with acyclovir. In: Maudgal PC, Missotten L. eds. Herpetic eye disease. Dordrecht, Boston, Lancaster: Junk, 1985; 319-25. 